This item was submitted to Loughborough's Research Repository by the author.

Items in Figshare are protected by copyright, with all rights reserved, unless otherwise indicated.

\title{
Zinc calixarene complexes for the ring opening polymerization of cyclic esters
}

\section{PLEASE CITE THE PUBLISHED VERSION}

http://dx.doi.org/10.1039/c4dt02226b

\section{PUBLISHER}

(c) Royal Society of Chemistry

\section{VERSION}

SMUR (Submitted Manuscript Under Review)

\section{PUBLISHER STATEMENT}

This work is made available according to the conditions of the Creative Commons Attribution-NonCommercialNoDerivatives 4.0 International (CC BY-NC-ND 4.0) licence. Full details of this licence are available at: https://creativecommons.org/licenses/by-nc-nd/4.0/

\section{LICENCE}

CC BY-NC-ND 4.0

\section{REPOSITORY RECORD}

Walton, Mark J., Simon J. Lancaster, Joseph A. Wright, Mark R.J. Elsegood, and Carl Redshaw. 2019. "Zinc Calixarene Complexes for the Ring Opening Polymerization of Cyclic Esters". figshare.

https://hdl.handle.net/2134/18309. 


\title{
Zinc Calixarene Complexes for the Ring Opening Polymerization of Cyclic Esters
}

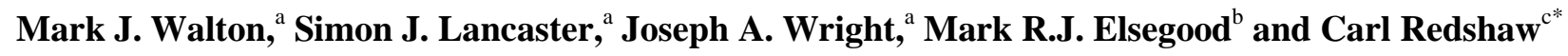 \\ Received (in $X X X, X X X) X$ th $X X X X X X X X X 20 X X$, Accepted $X$ th $X X X X X X X X X 20 X X$ \\ ${ }_{5}$ DOI: 10.1039/b000000x
}

Reaction of $\mathrm{Zn}\left(\mathrm{C}_{6} \mathrm{~F}_{5}\right)_{2}$.toluene (two equivalents) with 1,3-dipropoxy-p-tert-butyl-calix[4]arene $\left(\mathbf{L} 1 \mathrm{H}_{2}\right)$ led to the isolation of the complex $\left[\left\{\mathrm{Zn}\left(\mathrm{C}_{6} \mathrm{~F}_{5}\right)\right\}_{2} \mathbf{L}^{\mathbf{1}}\right]$ (1), whilst similar use of $\mathrm{Zn}(\mathrm{Me})_{2}$ resulted in the known complex [ $\left.\{\mathrm{Zn}(\mathrm{Me})\}_{2} \mathbf{L}^{1}\right]$ (2). Treatment of $\mathbf{L}^{1} \mathrm{H}_{2}$ with in-situ prepared $\mathrm{Zn}\left(\mathrm{N}\left(\mathrm{SiMe}_{3}\right)_{2}\right)_{2}$ in refluxing toluene led to the isolation of the compound $\left[\mathrm{ZnN}\left(\mathrm{SiMe}_{3}\right)_{2} \mathbf{L}^{\mathbf{1}}(\mathrm{Na})\right]$ (3). The stepwise reaction of $\mathbf{L}^{1} \mathrm{H}_{2}$ and 10 sodium hydride, followed by $\mathrm{ZnCl}_{2}$ and finally $\mathrm{NaN}\left(\mathrm{SiMe}_{3}\right)_{2}$ yielded the compound $\left[\mathrm{Zn}\left(\mathrm{N}\left(\mathrm{SiMe}_{3}\right)_{2}\right)_{2} \mathbf{L}^{\mathbf{1}}\right]$

(4). The reaction between three equivalents of $\mathrm{Zn}\left(\mathrm{C}_{6} \mathrm{~F}_{5}\right)_{2}$. toluene and oxacalix[3]arene $\left(\mathbf{L}^{2} \mathrm{H}_{3}\right)$ at room temperature formed the compound $\left\{\left[\mathrm{Zn}\left(\mathrm{C}_{6} \mathrm{~F}_{5}\right)\right]_{3} \mathbf{L}^{2}\right\}$ (5); heating of 5 in acetonitrile caused the ring opening of the parent oxacalix[3]arene and rearrangement to afford the complex

$\left[\left(\mathbf{L}^{2}\right) \mathrm{Zn}_{6}\left(\mathrm{C}_{6} \mathrm{~F}_{5}\right)(\mathrm{R})(\mathrm{RH}) \mathrm{OH} \cdot 5 \mathrm{MeCN}\right] \mathrm{R}=\mathrm{C}_{6} \mathrm{~F}_{5} \mathrm{CH}_{2}-\left(p-{ }^{\mathrm{t}} \mathrm{BuPhenolate}-\mathrm{CH}_{2} \mathrm{OCH}_{2}-\right)_{2}-p-{ }^{\mathrm{t}}$ BuPhenolate-

$\left.{ }_{15} \mathrm{CH}_{2} \mathrm{O}^{-}\right)^{3-}(\mathbf{6})$. The molecular structures of the new complexes $\mathbf{1}, \mathbf{3}$ and $\mathbf{6}$, together with that of the known complex 2, whose solid state structure has not previously been reported, have been determined.

Compounds $1,3-5$ have been screened for the ring opening polymerization (ROP) of $\varepsilon$-caprolactone ( $\varepsilon$ $\mathrm{CL}$ ) and rac-lactide. Compounds featuring a $\mathrm{Zn}-\mathrm{C}_{6} \mathrm{~F}_{5}$ fragment were found to be poor ROP pre-catalysts as they did not react with benzyl alcohol to form an alkoxide. By contrast, compound 4, which contains a

20 zinc silylamide linkage, was the most active of the zinc-based calix[4]arene compounds screened and was capable of ROP at ambient temperature with $65 \%$ conversion over $4 \mathrm{~h}$.

\section{Introduction}

A great number zinc-based ring opening polymerization (ROP) catalysts have been explored since the seminal work by Coates 25 and co-workers. ${ }^{1}$ The majority of these catalysts employ ligand systems such as diphenolates, ${ }^{2,}{ }^{3}$ or Schiff bases, ${ }^{4}$ whilst relatively few calixarene-based catalysts for the ROP of either lactides or lactones have been examined. ${ }^{5}$ Generally, ligands that are monoanionic are chosen for reaction with zinc precursors as 30 they will inevitably lead to a metal that still contains a viable nucleophilic group for ROP, which may be the reason that $p$-tertcalix[4]arenes have rarely been utilized. Vigalok and co-workers have had success with zinc alkyl-based calix[4]arenes and although the dialkoxycalix[4]arene ligand is dianionic when ${ }_{35}$ deprotonated its use leads to a dimetallic complex that can still contain a nucleophilic group. ${ }^{6}$ Indeed, in related work, we have accessed a highly selective and immortal magnesium based mononuclear complex $\left[\mathbf{L}^{3} \mathrm{Mg}(n-\mathrm{Bu})\right]$, where $\mathbf{L}^{3}$ is derived from tripropoxy-p-tert-butylcalix[4]arene, which exhibited exceptional 40 activity for the ROP of rac-lactide. ${ }^{7}$ Given zinc compounds are often synthesized due to their higher tolerance of water, ${ }^{8}$ we have initiated a programme to more fully explore both the coordination chemistry and catalysis of zinc-based calixarenes. Herein, we explore the use of the calix[4]arene ligand $\mathbf{L}^{1} \mathrm{H}_{2}$ and the oxacalix-

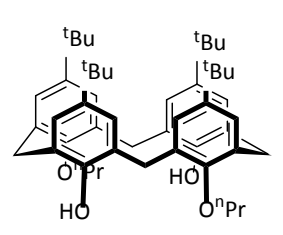

$\mathbf{L}^{1} \mathrm{H}_{2}$

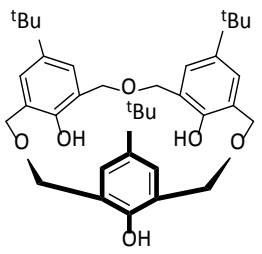

$\mathbf{L}^{2} \mathrm{H}_{3}$
Chart 1. Ligands utilized herein.

[3]arene ligand $\mathbf{L}^{2} \mathrm{H}_{3}$ (see Chart 1). ${ }^{9}$ Resulting zinc compounds have been subjected to both $\varepsilon$-caprolactone and rac-lactide ROP studies. The effect of additional chain transfer agents are 50 described, and the tacticity of the resulting polymers are discussed.

\section{Results and discussion}

\section{Calix[4]arene Complexes}

A number of new zinc-containing calix[4]arene complexes have 55 been synthesised and fully characterized. The synthetic procedures are outlined below in Scheme 1 . 


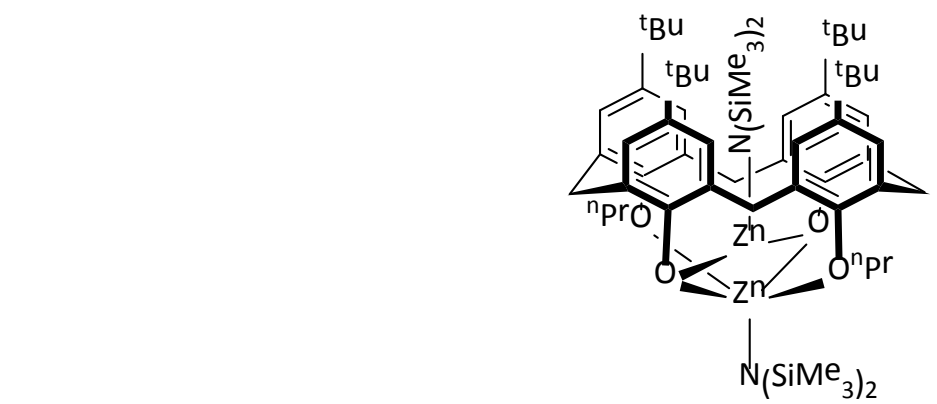

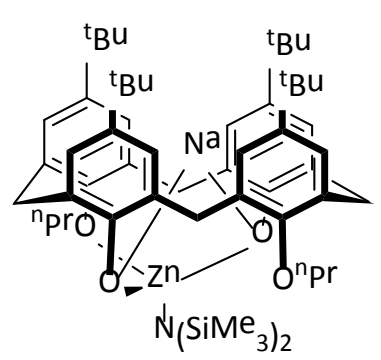

3

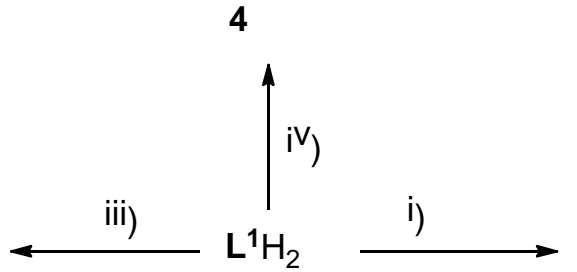

ii)

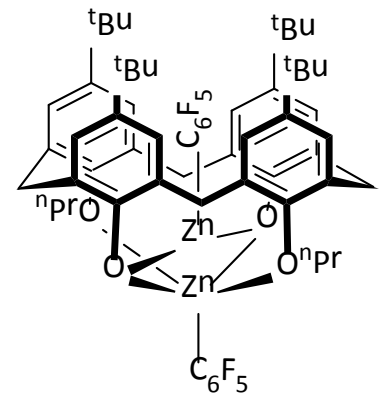

1

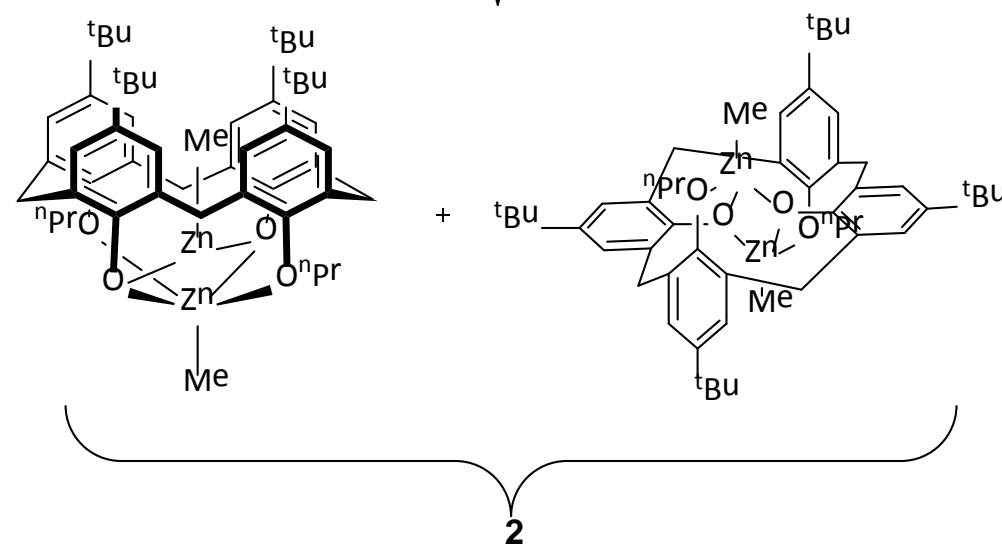

Scheme 1 Synthesis of zinc compounds 1 - 4. i) $2 \mathrm{Zn}\left(\mathrm{C}_{6} \mathrm{~F}_{5}\right)_{2}$.tol, toluene, reflux, $16 \mathrm{~h}$. ii) $2 \mathrm{ZnMe}$, toluene, RT, $16 \mathrm{~h}$. iii) 1$) 2 \mathrm{NaH}, \mathrm{THF}, 16 \mathrm{~h}$, room temperature, 2) $\left.\mathrm{ZnCl}_{2}, \mathrm{THF}, 2 \mathrm{~h}, \mathrm{RT}, 3\right) \mathrm{Na}\left(\mathrm{N}\left(\mathrm{SiMe}_{3}\right)_{2}\right), \mathrm{THF}, 2 \mathrm{~h}, \mathrm{RT}$. iv) $2 \mathrm{Zn}\left(\mathrm{N}\left(\mathrm{SiMe}_{3}\right)_{2}\right)_{2}$, toluene, reflux, $72 \mathrm{~h}$.

5 The compound 1,3-dipropoxy-p-tert-butyl-calix[4]arene $\left(\mathbf{L} \mathbf{1} \mathrm{H}_{2}\right)$ was synthesized as previously described. ${ }^{10,11}$ Treatment of $\mathbf{L}^{\mathbf{1}} \mathrm{H}_{2}$ with $\mathrm{Zn}\left(\mathrm{C}_{6} \mathrm{~F}_{5}\right)_{2}$. toluene (two equivalents) in refluxing toluene led to the isolation of the complex $\left[\left\{\mathrm{Zn}\left(\mathrm{C}_{6} \mathrm{~F}_{5}\right)\right\}_{2} \mathbf{L}^{\mathbf{1}}\right]$ (1) in good yield (54\%). A related $n$-propoxy calix[4]arene derivative, synthesized 10 via treatment with $\mathrm{ZnMe}_{2}$, was previously employed by Vigalok and co-workers, who reported that calix[4]arene derivatives containing smaller alkyl chains (at the lower rim) led to more complex products, including partial and 1,3-alternate cone conformations. $^{12}$ In the case of $\mathbf{1}$, the cone conformation was 15 isolated exclusively. Crystallization of compound 1 using hot acetonitrile led to the formation of clear blocks on slow cooling to ambient temperature, which proved suitable for single crystal $\mathrm{X}$-ray diffraction studies. Compound 1 crystallises with two different pentafluorophenyl zinc environments, one outside of the 20 calix[4]arene backbone and the other within the cavity. The exo zinc metal centre is five co-ordinate in a trigonal bipyramidal geometry bonding to all four of the calix[4]arene lower-rim oxygens, whereas the encapsulated zinc is trigonal planar and only binds to the 'non-propoxy' oxygen atoms. The pinched-cone 25 calixarene conformation arises due to the propoxy substitution and the spatial requirement of the $\mathrm{Zn}(2)$-bound $\mathrm{C}_{6} \mathrm{~F}_{5}$ group. The $\mathrm{Zn}(2)$ to arene distances of $c a$. $3.0 \AA$ are likely too long for these to be considered as $\mathrm{Zn} \cdots \pi$ interactions. The structure of compound 1 is depicted in Figure 1, with selected bond lengths 30 and angles given in the caption.

Disappointingly, the pre-polymerization screening of compound 1 indicated no reaction between the benzyl alcohol $(\mathrm{BnOH})$ and the $\mathrm{Zn}-\mathrm{C}_{6} \mathrm{~F}_{5}$ moiety, which was also the conclusion obtained by Schnee et al and Piedra-Arroni et al when $\mathrm{Zn}\left(\mathrm{C}_{6} \mathrm{~F}_{5}\right)_{2}$. toluene was 35 employed in the presence of either $\mathrm{BnOH}$ or amine/phosphine respectively. ${ }^{13,14}$ In such systems, the catalyst was thought to behave as a 'monomer activator' rather than proceeding via a 'coordination insertion' pathway; the lack of activity contrasts with a 
number of previous $\mathrm{Zn}-\mathrm{C}_{6} \mathrm{~F}_{5}$ containing compounds. ${ }^{13,14}$ To ensure that the polymerization would proceed through a 'coordination insertion' mechanism, the

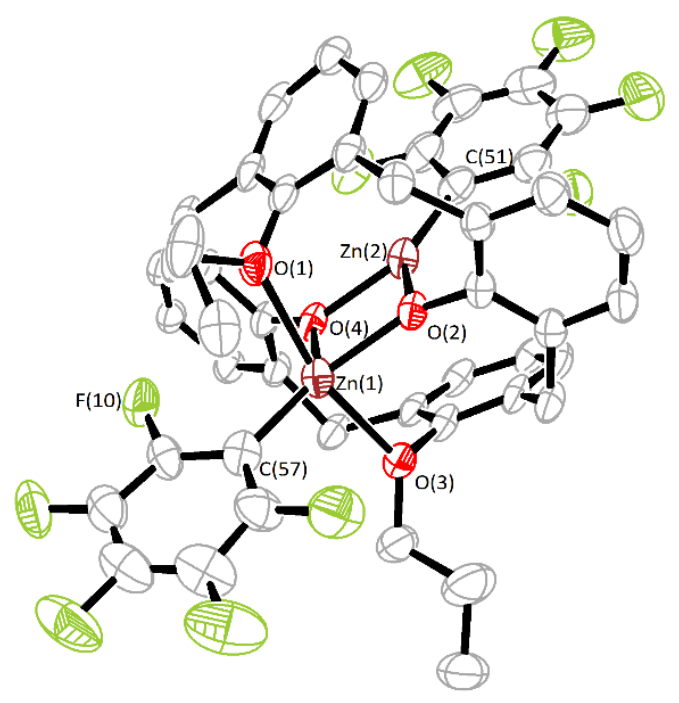

5 Figure 1 ORTEP representation of compound 1. Hydrogen atoms, tertbutyl groups and minor disordered components have been removed for clarity. Displacement ellipsoids are drawn at the $50 \%$ probability level. Selected bond lengths $(\AA)$ and angles $\left({ }^{\circ}\right): \mathrm{Zn}(1)-\mathrm{O}(1) 2.346(2), \mathrm{Zn}(1)-$ $\mathrm{O}(2) 1.968(2), \mathrm{Zn}(1)-\mathrm{O}(3) 2.312(2), \mathrm{Zn}(1)-\mathrm{O}(4)$ 1.964(2), $\mathrm{Zn}(2)-\mathrm{O}(2)$ 10 1.956(2), $\mathrm{Zn}(2)-\mathrm{O}(4)$ 1.931(2), $\mathrm{Zn}(1)-\mathrm{C}(57)$ 1.948(13), , $\mathrm{Zn}(2)-\mathrm{C}(51)$ 1.944(3), O(4)-Zn(1)-O(2) 79.16(8), O(4)-Zn(2)-O(2) 80.26(8), $\mathrm{Zn}(2)-\mathrm{O}(2)-\mathrm{Zn}(1) 99.78(8), \mathrm{Zn}(2)-\mathrm{O}(4)-\mathrm{Zn}(1) 100.80(8)$.

pentafluorophenyl moiety was substituted for a more nucleophilic group. To isolate a zinc alkoxide, firstly the methyl zinc 15 derivative (compound 2) was synthesized following the literature procedure. $^{6}$ Single crystals of compound 2 suitable for single crystal X-ray diffraction were grown from a saturated petroleum ether solution. The structure of 2 was initially assigned based on ${ }^{1} \mathrm{H}$ NMR spectroscopic data and is similar to the ethyl derivative. ${ }^{6}$ 20 Surprisingly, the crystal structure of 2 (See Figure 2) reveals both the cone and partial cone conformations within the unit cell (although the partial cone is better described as a chair conformation); the ${ }^{1} \mathrm{H}$ NMR spectrum $\left(\mathrm{CDCl}_{3}\right)$ indicates that only the cone conformation is present in solution, which is consistent 25 with the literature data. ${ }^{6}$

The cone conformation of $\mathbf{2}$ is similar to that observed in compound 1 , and again the exo-Zn is trigonal bipyramidal, whilst the endo- $\mathrm{Zn}$ is trigonal planar. In the chair conformation, there is a centre of inversion in the middle of the calix[4]arene. The zinc 30 metal centres are in the base of a trigonal pyramid with the $n$ propoxy oxygen at the apex.

Treatment of 2 with alcohol $\left(\mathrm{MeOH},{ }^{\mathrm{i}} \mathrm{PrOH}\right)$ at $-80{ }^{\circ} \mathrm{C}$ did not form the alkoxide; only starting material was detected. At higher temperatures, free calix[4]arene was formed, suggesting that the 35 alcohol displaced the calix[4]arene; a similar result was reported by Drouin et al. ${ }^{15}$

Zinc silylamides have previously been shown to be active for ROP of $L$-lactide and as such the synthesis of a calix[4]arene zinc silylamide was targeted. Treatment of $\mathbf{L}^{\mathbf{1}} \mathrm{H}_{2}$ with $\mathrm{Zn}\left(\mathrm{N}\left(\mathrm{SiMe}_{3}\right)_{2}\right)_{2}$, 40 which was synthesized in situ, from the sodium salt, in refluxing toluene led to the isolation of compound 3. Rather than the expected formation of a dizinc silylamide species, where one $\mathrm{Zn}-\mathrm{N}\left(\mathrm{SiMe}_{3}\right)_{2}$ fragment is present in the cavity, compound 3 contains a sodium cation within the cavity. The sodium cation 45 likely originates from unreacted sodium hexamethyldisilazane.
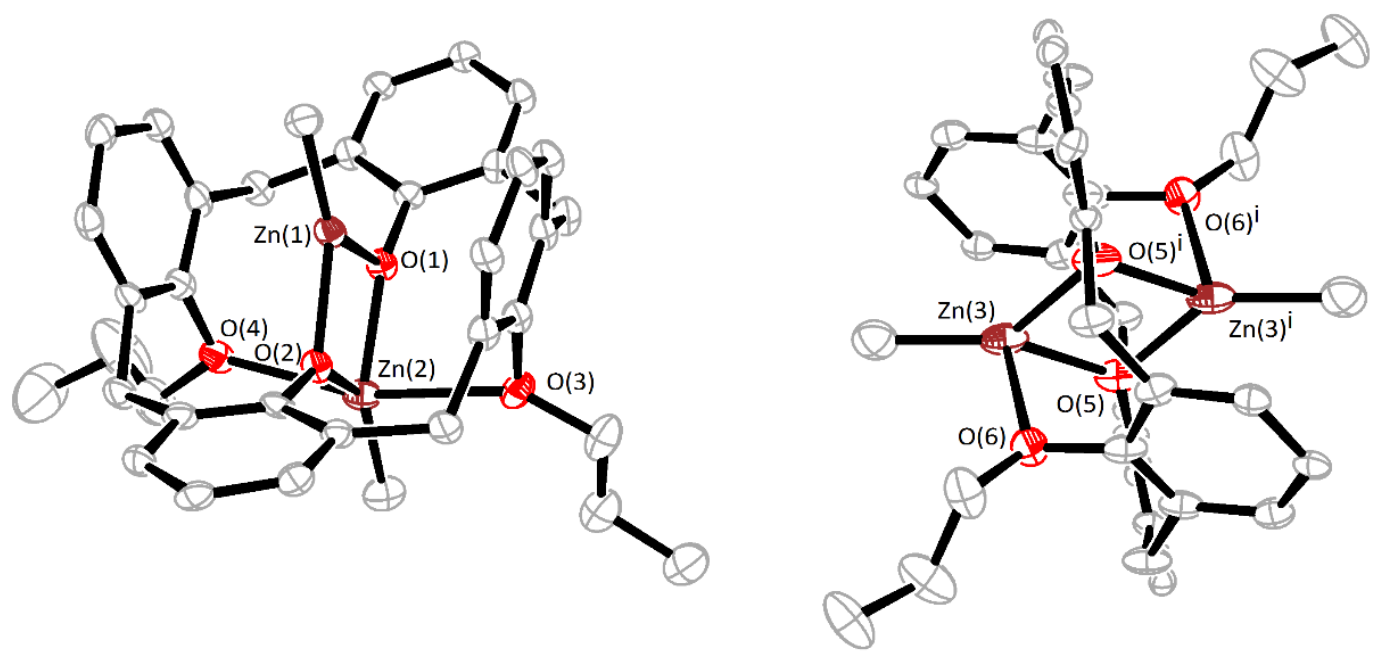

Figure 2 ORTEP representation of compound 2. Hydrogen atoms, tert-butyl groups and minor disorder components have been removed for clarity. Displacement ellipsoids are drawn at the $50 \%$ probability level. Selected bond lengths $(\AA \AA)$ and angles $\left({ }^{\circ}\right)$ : Cone: $C(51)-Z n(1) 1.942(5), C(52)-Z n(2)$ 50 1.955(5), O(1)-Zn(1) 1.972(3), O(1)-Zn(2) 1.978(3), O(2)-Zn(1) 1.970(3), O(2)-Zn(2) 1.984(3), O(4)-Zn(2) 2.360(3), Zn(1)-O(1)-Zn(2) 101.26(14), $\mathrm{Zn}(1)-\mathrm{O}(2)-\mathrm{Zn}(2)$ 101.12(13), O(2)-Zn(1)-O(1) 78.95(13), C(52)-Zn(2)-O(1) 139.96(19), C(52)-Zn(2)-O(2) 141.36(19), O(1)-Zn(2)-O(2) 78.47(13). Partial Cone: C(78)-Zn(3) 1.941(6), O(5)-Zn(3) 1.981(4), O(5)-Zn(3) $1.985(4), O(6)-Z n(3) 2.211(3), Z n(3)-O(5)^{i} 1.985(4), Z n(3)-O(5)-$ $\mathrm{Zn}(3)^{\mathrm{i}} 104.49(16), \mathrm{O}(5)-\mathrm{Zn}(3)-\mathrm{O}(5)^{i} 75.51(16), \mathrm{O}(5)-\mathrm{Zn}(3)-O(6) 86.70(13), \mathrm{O}(5)^{\mathrm{i}}-\mathrm{Zn}(3)-O(6) 90.36(14)$. 


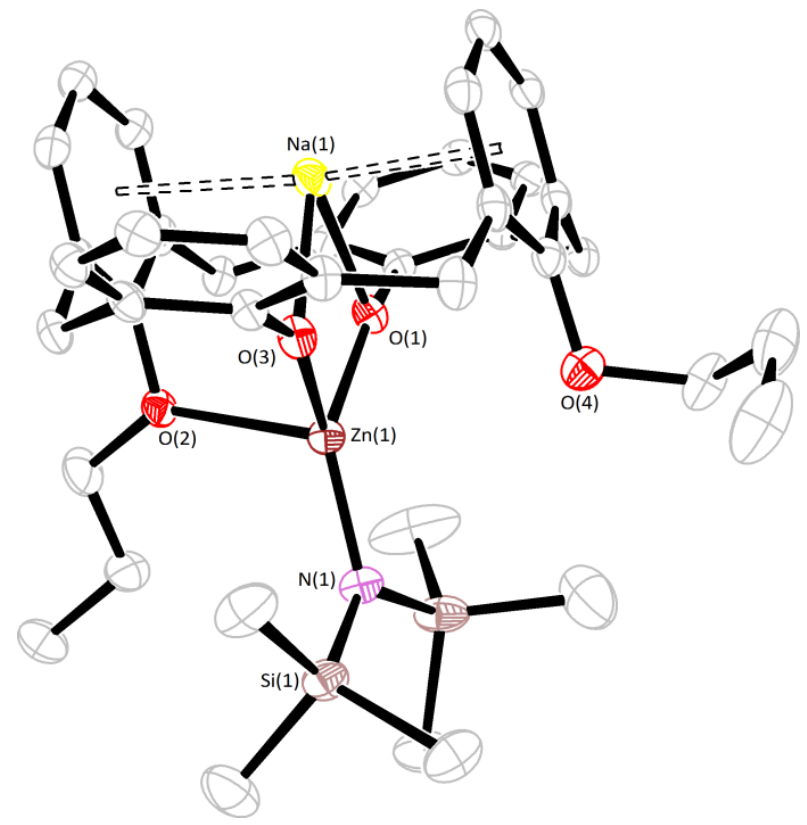

Figure 3 ORTEP representation of compound 3. Hydrogen atoms, tert5 butyl groups and disorder have been removed for clarity. Displacement ellipsoids are drawn at the $50 \%$ probability level. Selected bond lengths $(\AA))$ and angles $\left({ }^{\circ}\right): \operatorname{Zn}(1)-\mathrm{N}(1)$ 1.8929(13), $\mathrm{Zn}(1)-\mathrm{O}(1) \quad 1.9297(10)$, $\mathrm{Zn}(1)-\mathrm{O}(3) \quad 1.9402(10), \quad \mathrm{Zn}(1)-\mathrm{O}(2) \quad 2.2760(10), \quad \mathrm{N}(1)-\mathrm{Zn}(1)-\mathrm{O}(1)$ 131.42(5), $N(1)-Z n(1)-O(3) \quad 134.32(5), O(1)-Z n(1)-O(3)$ 88.46(5), ${ }_{10} \mathrm{~N}(1)-\mathrm{Zn}(1)-\mathrm{O}(2)$ 109.26(5), O(1)-Zn(1)-O(2) 87.08(4), O(3)-Zn(1)$\mathrm{O}(2)$ 91.34(4).

Single, rod-like, crystals were obtained on prolonged standing of a petroleum ether solution of $\mathbf{3}$ at ambient temperature. The crystal structure was determined by X-ray diffraction (Figure 3).

15 The zinc centre is bound to three of the oxygens of the calixarene, the two phenolic oxygens and one $n$-propoxy oxygen. As expected, the dative $\mathrm{O}-\mathrm{Zn}$ bond length is significantly longer than the other two, viz 2.2760(10) vs. 1.9297(10) and 1.9402(10) $\AA$; the $\mathrm{N}-\mathrm{Zn}$ bond is $1.8929(13) \AA$. The sodium cation occupies 20 the calix[4]arene cavity and is $\pi$-bonded to two opposite aryl rings, both $\eta^{6}$. The $\mathrm{Na}(1)$ to centroid distances are 2.741 and $2.607 \AA$. The interaction between the sodium cation and one of the $\eta^{6}$-centroids causes a pinching of the calixarene so that the final OR group is far enough removed that it does not participate 25 in dative bonding to the zinc; the latter is therefore in the base of a trigonal pyramid rather than in the trigonal bipyramidal geometry seen for 1 . The sodium and zinc centres are 3.1725(7) $\AA$ apart. The target dizinc silylamide, compound 4, was synthesized from the reaction between two equivalents of zinc 30 bis(hexamethyldisilyl amide), which has been vigorously separated, and $\mathbf{L}^{1} \mathrm{H}_{2}$ in toluene. Attempts to crystalize the product from THF/light petroleum, acetonitrile and pentane were unsuccessful; the compound was exceptionally soluble in these solvents. The volatiles from the reaction were removed in vacuo 35 to give a yellow solid. The ${ }^{1} \mathrm{H}$ NMR spectrum, elemental analysis and mass spectrum all match the structure as depicted in Scheme 1. The ${ }^{1} \mathrm{H}$ NMR spectrum is consistent with the calix[4]arene possessing a cone conformation and is similar to the recorded spectrum for 1 .

40

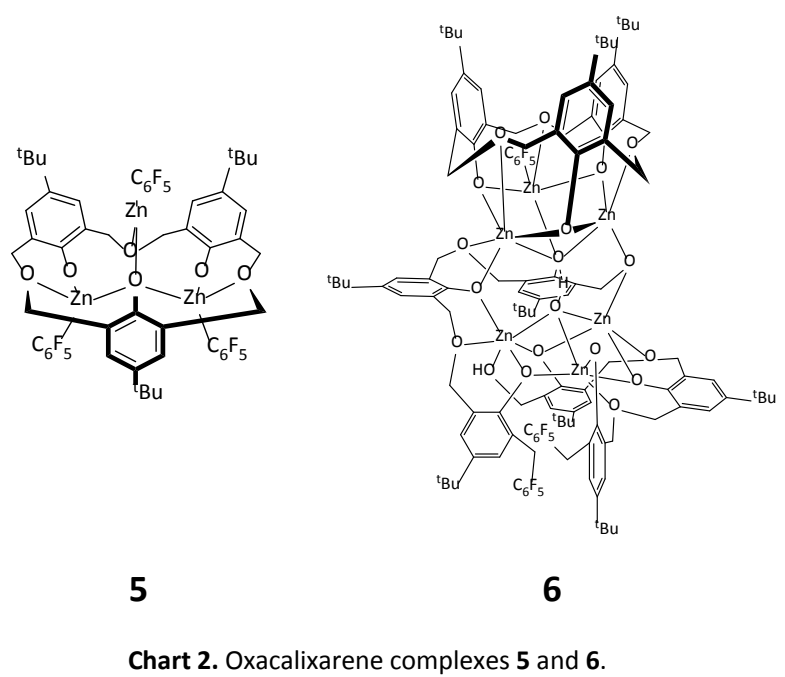

Oxacalix[3]arene complexes

For comparison we have prepared the related oxacalixarene complexes. The reaction between three equivalents of ${ }_{45} \mathrm{Zn}\left(\mathrm{C}_{6} \mathrm{~F}_{5}\right)_{2}$.toluene and oxacalix[3]arene $\left(\mathrm{L}^{2} \mathrm{H}_{3}\right)$ at room temperature led to the formation of compound 5 after removal of volatiles. However, on attempted crystallisation from hot acetonitrile, ring opening of the parent oxacalix[3]arene and rearrangement to complex $\mathbf{6}$ was observed. The ability of an 50 electrophilic species to open the ether linkages of the oxacalix backbone is not unprecedented, for example Iglesia and coworkers proposed a similar product from a $\mathrm{Ti} / \mathrm{SiO}_{2}$ grafted oxacalix[3]arene, ${ }^{17}$ however this is the first structurally characterised result.

55 Unfortunately, suitable single crystals of compound 5 could not be obtained. The ${ }^{1} \mathrm{H}$ NMR spectra are consistent with the complex existing in a partial cone conformation: there are three distinct sets of doublets for each of the methylene bridges and there is a two to one integration for the two discrete tert-butyl ${ }^{60}$ peaks. The ${ }^{19} \mathrm{~F}$ NMR spectra also show a two to one integration for each of the ortho- and para-fluorine signals; the meta-fluorine signals overlap. Compound 5 has also been characterised by mass spectroscopy and elemental analysis, both of which are consistent with the structure depicted in chart 2.

65 The structure of the ring opened oxacalix[3]arene compound 6 was determined by single crystal X-ray diffraction, which revealed the presence of three separate oxacalix[3]arene ligands within the molecule, two of which have been ring opened with formation of two carbon- $\mathrm{C}_{6} \mathrm{~F}_{5}$ bonds and a protonated oxygen 70 which is involved either in hydrogen bonding to an acetontrile molecule or an oxygen anion that forms two short bonds with two $\mathrm{Zn}^{2+}$ centres (See Figure 4). The remaining oxacalix[3]arene remains intact. There are six zinc metal centres within the compound, one of which is bound to a $\mathrm{C}_{6} \mathrm{~F}_{5}$ ring. The core of the 75 molecule consists of two $\mathrm{Zn}_{3} \mathrm{O}_{4}$ cubes missing one corner, linked via two $\mathrm{O}$ atoms and supported with an $\mathrm{O}-\mathrm{H} \cdots \mathrm{O}$ H-bond (see Table 1). The resulting ${ }^{1} \mathrm{H}$ NMR spectrum is complex due to lack of symmetry 


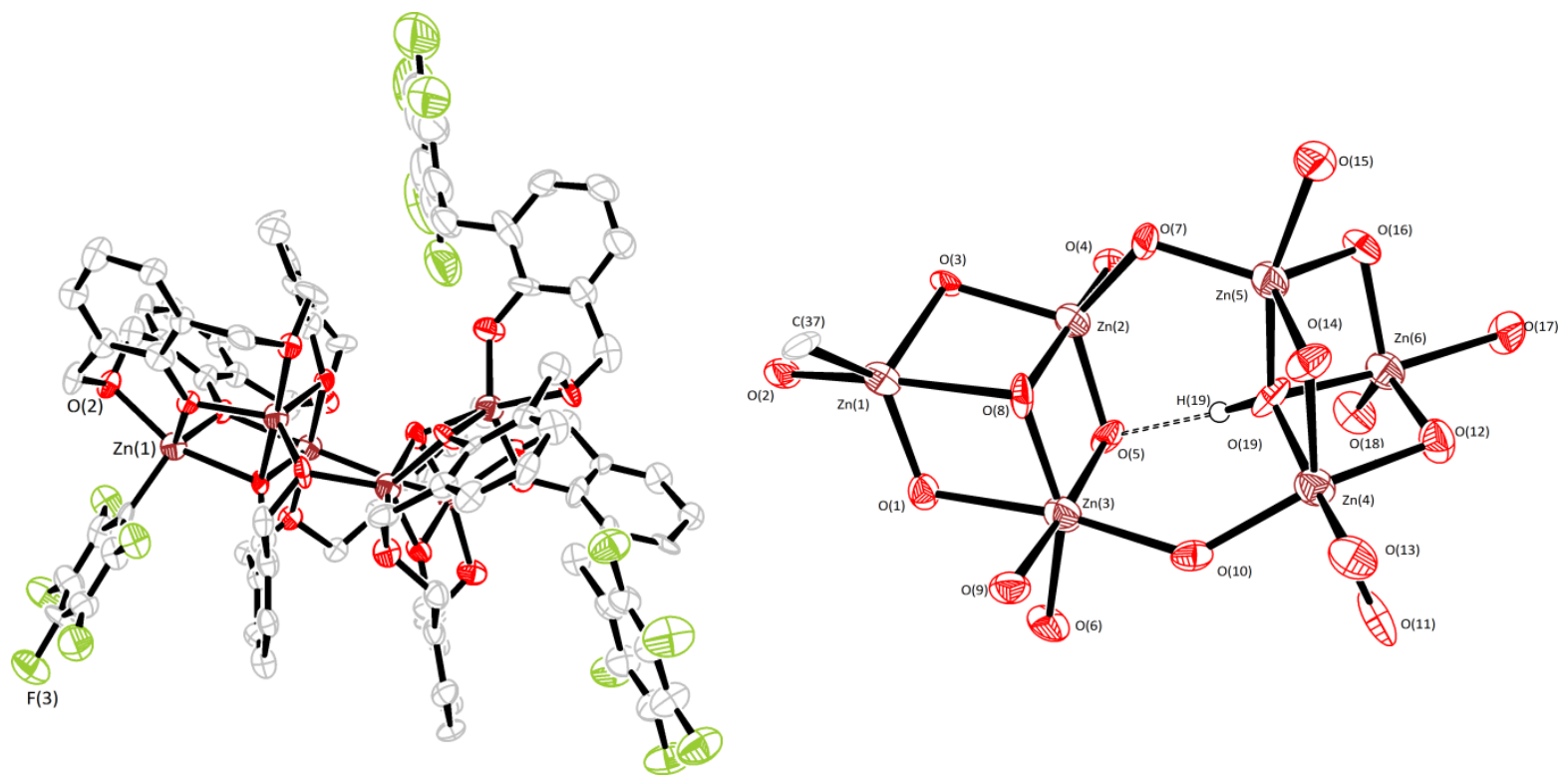

Figure 4 ORTEP representation of compound 6 (left) and the core of compound 6 (right). Hydrogen atoms except for those participating in hydrogen bonding in the core of compound 6 (H19), tert-butyl groups, solvent molecules and minor disorder components have been removed for clarity. Displacement ellipsoids are drawn at the $50 \%$ probability level. Selected bond lengths (Å): Zn1-01 1.966(8), Zn1-C37 1.999 (13), Zn1-03 2.047 (8), Zn1-O2 2.156(8), Zn1-08 2.241(7), Zn2-07 1.942 (8), Zn2-04 2.014 (8) Zn2-03 2.040 (7), Zn2-05 2.043 (9), Zn2-08 2.101(8), Zn3-08 2.019 (9), 5 Zn3-06 2.047 (8), Zn3-010 2.099(8), Zn3-05 2.105 (8), Zn3-09 2.147(8), Zn3-01 2.270 (7), Zn4-019 2.029(8), Zn4-013 2.051(10), Zn4-010 2.065(8), Zn4-012 2.071 (8), Zn4-014 2.120 (9), Zn5-07 1.941 (7), Zn5-014 1.968 (8), Zn5-016 2.027(8), Zn5-019 2.042 (8), Zn5-015 2.154 (9), Zn6-018 1.895 (8), Zn6-012 2.015(9), Zn6-016 2.021(8), Zn6-019 2.025 (8), Zn6-017 2.132(8).

with nine separate tert-butyl signals. The ${ }^{19} \mathrm{~F}$ NMR spectrum consists of nine peaks in total for the three $\mathrm{C}_{6} \mathrm{~F}_{5}$ fragments.

10

Table 1. Hydrogen-bond geometry $\left(\AA,^{\circ}\right)$ for 6

$$
\begin{array}{llll}
\mathrm{D}-\mathrm{H} \cdots \mathrm{A} & \mathrm{D}-\mathrm{H} & \mathrm{H} \cdots \cdot \mathrm{A} & \mathrm{D} \cdots A \mathrm{~A} \\
\mathrm{O} 19-\mathrm{H} 19 \bullet \bullet \mathrm{O} 5 & 1.00 & 1.84 & 2.786(11)
\end{array}
$$

\section{${ }_{15}$ Polymerization Screening}

Compounds $1,3-5$ were screened for the polymerization of $\varepsilon$ caprolactone $(\varepsilon-\mathrm{CL})$ and rac-lactide. The results are presented in Table 1.

Compound 1 was screened for the polymerization of $\varepsilon$ 20 caprolactone at room temperature and was found to be inactive when using dichloromethane, tetrahydrofuran or toluene as solvent (Table 2, runs $1-3$ ). Only at temperatures greater than 80 ${ }^{\circ} \mathrm{C}$ was compound 1 found to be active for the ROP of $\varepsilon$ caprolactone; attempting polymerization without benzyl alcohol 25 present was detrimental to the catalytic system (Table 2, runs 5 7). Furthermore, compound 1 was only active for the ROP of raclactide at high temperature. In both cases ( $\varepsilon$-caprolactone and rac-lactide) high conversion rates can be achieved at high temperature, however the resulting polymer molecular weight is

30 much lower than expected; this indicates that there are significant trans-esterification reactions occurring at such temperatures. Screening of compound 4 , where the $\mathrm{C}_{6} \mathrm{~F}_{5}$ groups have been replaced with $\mathrm{N}\left(\mathrm{SiMe}_{3}\right)_{2}$, revealed that the system was active at room temperature and converted 100 equivalents of $\varepsilon$ 35 caprolactone with $65 \%$ completion over $4 \mathrm{~h}$ in toluene (Table 2 , run 13). The polymer molecular weights were close to the expected values; lower activity was observed using THF. This compares favourably with the ROP activity ( $43 \%$ over $24 \mathrm{~h}$ at 60 $\left.{ }^{\circ} \mathrm{C}\right)$ observed for the hexanuclear complex $\left[\mathrm{L}^{2}(\mathrm{ZnEt})_{4} \mathrm{Zn}_{2}\left(\mathrm{CH}_{3} \mathrm{CN}\right.\right.$ $\left.40)_{4}(\mu-\mathrm{OEt})_{2}\right]^{9 a}$

Compound 3, which differs from compound 4 by replacement of the $\mathrm{Zn}-\mathrm{N}\left(\mathrm{SiMe}_{3}\right)_{2}$ in the calix[4]arene cavity with a sodium cation, was not active under the same conditions as for 4 . Compound 5 was only active for the ROP of rac-lactide and $\varepsilon$ 45 caprolactone at high temperatures $\left(100{ }^{\circ} \mathrm{C}\right)$ and gave $\varepsilon^{-}$ caprolactone molecular weight much lower than expected. The polymerization using 5 was further complicated due to the probability of forming a species similar to compound 6; the latter was not screened for polymerization. Interestingly, despite the

50 aforementioned trans-esterification at high temperatures, all of the zinc compounds screened afforded products with low PDI values $(1.06$ - 1.48). We also note that for the $\left[\mathrm{L}^{2}(\mathrm{ZnEt})_{4} \mathrm{Zn}_{2}\left(\mathrm{CH}_{3} \mathrm{CN}\right)_{4}(\mu-\mathrm{OEt})_{2}\right]^{9 \mathrm{a}}$ the use of low co-catalyst loadings resulted in molecular weights far lower than the 55 calculated values, indicating the importance of back biting reactions. Similarly for $\left[\mathbf{L}^{2}(\mathrm{ZnEt})_{4} \mathrm{Zn}_{2}\left(\mathrm{CH}_{3} \mathrm{CN}\right)_{4}(\mu-\mathrm{OEt})_{2}\right]^{9 \mathrm{a}}$, the polydispersity $(\leq 1.3)$ was not hampered by such back biting.

\section{Experimental}

60 All manipulations were carried out under an atmosphere of nitrogen using standard Schlenk and cannula techniques or in a conventional nitrogen-filled glove-box. Solvents were refluxed over an appropriate drying agent, and distilled and degassed prior to use. Elemental analyses were performed by the microanalytical 65 services at London Metropolitan University. NMR spectra were recorded on Bruker Ascend 500/300 MHz spectrometers at 298 $\mathrm{K}$; chemical shifts are referenced to the residual protio impurity of the deuterated solvent. IR spectra (Nujol mulls) were recorded 
on Perkin-Elmer 577 and 457 grating spectrophotometers. $\mathbf{L}^{\mathbf{1}} \mathrm{H}_{2}$ and $\mathbf{L}^{2} \mathrm{H}_{3}$ were synthesized by the reported procedures. ${ }^{10,18}$ racLactide was purchased from Sigma Aldrich and used without further purification. GPC analysis was performed on a Polymer
5 Laboratories, PL-GPC 50 using THF at $0.5 \mathrm{~mL}$ 'min flow rate and $30{ }^{\circ} \mathrm{C}$, corrected by the Mark-Houwink factor (0.58).

Table 2 ROP of $\varepsilon$-caprolactone/rac-lactide using zinc compounds 1, 3 - 5 .

\begin{tabular}{|c|c|c|c|c|c|c|c|c|c|c|}
\hline Run & Pre- Cat & Solvent & Monomer & $\mathrm{T}\left({ }^{\circ} \mathrm{C}\right)$ & $\mathrm{M}: \mathrm{BnOH}$ & Time (h) & Conv $^{\mathrm{a}}(\%)$ & $M_{\mathrm{n}, \mathrm{GPC}}$ & $M_{\mathrm{n}, \mathrm{Cal}}$ & PDI \\
\hline 1 & 1 & Toluene & $\varepsilon$-caprolactone & 20 & $25: 1$ & 24 & - & & & \\
\hline 2 & 1 & THF & $\varepsilon$-caprolactone & 20 & $25: 1$ & 24 & - & & & \\
\hline 3 & 1 & $\mathrm{CH}_{2} \mathrm{Cl}_{2}$ & $\varepsilon$-caprolactone & 20 & $25: 1$ & 24 & - & & & \\
\hline 4 & 1 & Toluene & $\varepsilon$-caprolactone & 60 & $25: 1$ & 24 & - & & & \\
\hline 5 & 1 & Toluene & $\varepsilon$-caprolactone & 80 & $25: 1$ & 3 & 96 & & & \\
\hline 6 & 1 & Toluene & $\varepsilon$-caprolactone & 100 & $25: 0$ & 2 & 95 & & & \\
\hline 7 & 1 & Toluene & $\varepsilon$-caprolactone & 100 & $25: 1$ & 1 & 98 & & & \\
\hline 8 & 1 & Toluene & $\varepsilon$-caprolactone & 100 & $100: 1$ & 3 & 85 & 4,760 & 9,700 & 1.06 \\
\hline 9 & 1 & Toluene & $\varepsilon$-caprolactone & 100 & $200: 1$ & 4 & 90 & 7,600 & 20,500 & 1.48 \\
\hline 10 & 3 & THF & $\varepsilon$-caprolactone & 20 & $100: 1$ & 24 & 21 & & & \\
\hline 11 & 3 & Toluene & $\varepsilon$-caprolactone & 20 & $100: 1$ & 24 & 21 & & & \\
\hline 12 & 4 & THF & $\varepsilon$-caprolactone & 20 & $100: 1$ & 4 & 27 & & & \\
\hline 13 & 4 & Toluene & $\varepsilon$-caprolactone & 20 & $100: 1$ & 4 & 65 & 11,900 & 7,920 & 1.27 \\
\hline 14 & 4 & Toluene & $\varepsilon$-caprolactone & 20 & $100: 2$ & 4 & 49 & 4,740 & 2,800 & 1.27 \\
\hline 15 & 4 & Toluene & $\varepsilon$-caprolactone & 20 & $200: 4$ & 4 & 47 & 4,500 & 2,680 & 1.18 \\
\hline 16 & 5 & Toluene & $\varepsilon$-caprolactone & 20 & $100: 1$ & 24 & - & & & \\
\hline 17 & 5 & Toluene & $\varepsilon$-caprolactone & 40 & $100: 1$ & 24 & - & & & \\
\hline 18 & 5 & Toluene & $\varepsilon$-caprolactone & 80 & $100: 1$ & 2 & 77 & 2,800 & 8,800 & 1.07 \\
\hline 19 & 5 & Toluene & $\varepsilon$-caprolactone & 100 & $100: 1$ & 1 & 95 & 2,970 & 10,800 & 1.11 \\
\hline 20 & 1 & Toluene & rac-lactide & 100 & $100: 1$ & 3 & $90\left(P_{r}=0.62\right)$ & 1,440 & 13,000 & 1.26 \\
\hline 21 & 4 & Toluene & rac-lactide & 20 & $100: 1$ & 5 & $64\left(P_{r}=0.54\right)$ & 8,970 & 9,220 & 1.13 \\
\hline 22 & 5 & Toluene & rac-lactide & 100 & $100: 1$ & 3 & 52 & & & \\
\hline
\end{tabular}

Conditions: Polymerisation carried out using $60 \mu \mathrm{mol}$ catalyst at $20^{\circ} \mathrm{C}$, [Monomer $]_{0}=0.6 \mathrm{M}, 10 \mathrm{~mL}$ solvent, ROH taken from a ROH/toluene solution. ${ }^{a}$ 10 Determined by NMR spectroscopy, ${ }^{\mathrm{b}}$ Calculated from ([Monomer $\left.]_{0} /[\mathrm{OH}]_{0}\right)$ x conv.(\%) x Monomer molecular weight + ROH. $M_{\mathrm{n}} \mathrm{GPC}$ values corrected considering Mark-Houwink factors (0.58 polylactide/0.56 poly( $\varepsilon$-caprolactone) ) from polystyrene standards in THF. ${ }^{19,20}$

\section{Synthesis of $\mathrm{L}^{1}\left(\mathrm{ZnC}_{6} \mathrm{~F}_{5}\right)_{2}(1)$}

1,3-dipropoxy-p-tert-butylcalix[4]arene $(0.75 \mathrm{~g}, 1.0 \mathrm{mmol})$ and bis(pentafluorophenyl)zinc.toluene $(0.98 \mathrm{~g}, 2.0 \mathrm{mmol})$ were 15 dissolved in toluene $(30 \mathrm{ml})$ and refluxed for $16 \mathrm{~h}$. The volatiles were removed in vacuo. The residue was extracted into warm acetonitrile and after 24 h clear blocks of 1 formed. (0.65 g, 54 \%). MS (EI, m/z) $1196[\mathrm{M}]^{+}, 1181$ [M-Me ${ }^{+}$. Found: C, 62.06; H, 5.42. $\mathrm{C}_{62} \mathrm{H}_{66} \mathrm{~F}_{10} \mathrm{O}_{4} \mathrm{Zn}_{2}$ requires $\mathrm{C}, 62.27 ; \mathrm{H}, 5.56 \%$. IR (ATR, $\mathrm{cm}^{-}$ $\left.{ }_{20}{ }^{1}\right)$ : $2953 \mathrm{~m}, 1738 \mathrm{~m}, 1632 \mathrm{w}, 1505 \mathrm{~m}, 1457 \mathrm{~s}, 1363 \mathrm{~m}, 1256 \mathrm{~m}$, $1203 \mathrm{~m}, 1097 \mathrm{w}, 1074 \mathrm{~m}, 1056 \mathrm{~m}, 986 \mathrm{~m}, 953 \mathrm{~s}, 917 \mathrm{w}, 831 \mathrm{w}, 755 \mathrm{~m}$, 721w, 526m. ${ }^{1} \mathrm{H}$ NMR $\left(\mathrm{CDCl}_{3}\right): 7.13$ (s, 4H, Ar- $H$ ), 6.83 (s, 4H, $\operatorname{Ar}-H), 4.43\left(\mathrm{~d}, 4 \mathrm{H}, \mathrm{J}=17.5\right.$, endo- $\left.\mathrm{CH}_{2}\right), 3.82$ (t, $4 \mathrm{H}, J=10.0 \mathrm{~Hz}$, $\mathrm{OCH}_{2} \mathrm{CH}_{2} \mathrm{CH}_{3}$ ), 3.39 (d, 4H, $J=17.5$, exo- $\left.\mathrm{CH}_{2}\right) 1.54$ (m, $4 \mathrm{H}$, $\left.{ }_{25} \mathrm{CH}_{2} \mathrm{CH}_{2} \mathrm{CH}_{3}\right), 1.39$ (s, 18H, C $\left.\left(\mathrm{CH}_{3}\right)_{3}\right), 0.68\left(\mathrm{~m}, 24 \mathrm{H}, \mathrm{C}\left(\mathrm{CH}_{3}\right)_{3}+\right.$ $\left.\mathrm{CH}_{2} \mathrm{CH}_{2} \mathrm{CH}_{3}\right) .{ }^{19} \mathrm{~F}\left(\mathrm{CDCl}_{3}\right):-113.9(\mathrm{~m}, 2 \mathrm{~F}, \mathrm{o}-\mathrm{ArF}),-114.0$ (m, 2F, $o$-ArF) -154.8 (t, 1F, J = 19.3, p-ArF), -158.0 (t, 1F, J = 19.3, pArF), -160.5 (m, 2F, m-ArF), -164.4 (m, 2F, m-ArF).

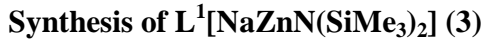

30 1,3-dipropoxy-p-tert-butylcalix[4]arene (2.00 g, $2.73 \mathrm{mmol}$ ) and sodium hydride (140 mg, $5.83 \mathrm{mmol}$ ) were dissolved in THF (30 $\mathrm{ml})$. The solution was stirred for $1 \mathrm{~h}$ and then $\mathrm{ZnCl}_{2}(0.37 \mathrm{~g}, 2.73$ mmol) was added as a THF solution $(15 \mathrm{ml})$. The solution was stirred for a further $1 \mathrm{~h}, \mathrm{NaN}\left(\mathrm{SiMe}_{3}\right)_{2}(2.73 \mathrm{ml}, 1 \mathrm{M}$ solution in $35 \mathrm{THF}$ ) was then added and after $1 \mathrm{~h}$, the volatiles were removed in vacuo. The residue was extracted in petroleum ether and on standing (2 h) clear rods of compound 3 formed. (1.32 g, $50 \%$ ). MS (EI, m/z): $977\left[\mathrm{M}^{+}\right]$. Found: C, 68.44; H 8.72; N, 1.49. $\mathrm{C}_{56} \mathrm{H}_{84} \mathrm{NNaO}_{4} \mathrm{Si}_{2} \mathrm{Zn}$ requires $\mathrm{C}, 68.65 ; \mathrm{H}, 8.64 ; \mathrm{N}, 1.43 \%$. IR 40 (ATR, cm ${ }^{-1}$ ): 2954s, 2903m, 2870m, 1453s, 1350m, 1301m, 1249m, 1194m, 1097w, 995m, 930s, 872m, 839s, 752m. ${ }^{1} \mathrm{H}$ NMR $\left(\mathrm{CDCl}_{3}\right): \delta=7.13$ (s, 4H, Ar-H), 6.70 (s, 2H, Ar-H), 6.67 (s, $2 \mathrm{H}, \mathrm{Ar}-\mathrm{H}$ ), 4.38 (d, $2 \mathrm{H}, J=13.1$, endo- $\mathrm{CH}_{2}$ ), 4.32 (d, $2 \mathrm{H}, J=$ 12.9, endo- $\mathrm{CH}_{2}$ ), 4.26 (t, $\left.2 \mathrm{H}, J=8.02, \mathrm{OCH}_{2}\right), 3.77$ (t, $2 \mathrm{H}, J=$ 45 7.80, $\mathrm{OCH}_{2} \mathrm{CH}_{2} \mathrm{CH}_{3}$ ), 3.18 (d, $2 \mathrm{H}, \mathrm{J}=13.1$, exo- $\mathrm{CH}_{2} \mathrm{CH}_{2} \mathrm{CH}_{3}$ ), $3.13\left(\mathrm{~d}, 4 \mathrm{H}, J=12.7\right.$, exo-CH $\left.\mathrm{CH}_{2}\right), 1.99(\mathrm{~m}, 2 \mathrm{H}, J=7.68$, $\mathrm{OCH}_{2} \mathrm{CH}_{2} \mathrm{CH}_{3}$ ), $1.46\left(\mathrm{~m}, 2 \mathrm{H}, J=7.62, \mathrm{OCH}_{2} \mathrm{CH}_{2} \mathrm{CH}_{3}\right), 1.39$ (s, $\left.9 \mathrm{H}, \mathrm{C}\left(\mathrm{CH}_{3}\right)_{3}\right), 1.37$ (s, 9H, C( $\left.\left(\mathrm{CH}_{3}\right)_{3}\right), 0.97$ (s, 9H, C( $\left.\left(\mathrm{CH}_{3}\right)_{3}\right), 0.94$ (s, 9H, C $\left.\left(\mathrm{CH}_{3}\right)_{3}\right), 0.91$ (t, 3H, $\left.J=7.00, \mathrm{OCH}_{2} \mathrm{CH}_{2} \mathrm{CH}_{3}\right), 0.52$ (t, $\left.503 \mathrm{H}, J=7.28, \mathrm{OCH}_{2} \mathrm{CH}_{2} \mathrm{CH}_{3}\right), 0.11$ (s, $18 \mathrm{H}, \mathrm{N}\left(\mathrm{SiMe}_{3}\right)_{2} \cdot{ }^{13} \mathrm{C} \mathrm{NMR}$ $\left(\mathrm{CDCl}_{3}\right): \delta=162.5,157.3,154.0,153.5,136.9,136.0,132.1$, 131.6, 125.5, 125.4, 123.3, 122.2, 78.1, 77.5, 34.2, 34.0, 33.9, 33.7, 33.7, 32.4, 32.1, 31.4, 31.3, 23.0, 22.5, 10.1, 9.5, 5.5, 2.7.

\section{Synthesis of $\mathrm{L}^{1}\left[\mathrm{ZnN}\left(\mathrm{SiMe}_{3}\right)_{2}\right]_{2}$ (4)}

55 1,3-dipropoxy-p-tert-butylcalix[4]arene (2.00 g, $2.73 \mathrm{mmol})$ was dissolved in toluene $(30 \mathrm{ml})$ and zinc bis(bis(trimethylsilyl)amide) (2.20 ml, $5.46 \mathrm{mmol})$ was added. The solution was heated at reflux for $72 \mathrm{~h}$. The volatiles were removed in vacuo and the residue extracted with pentane. The 60 pentane solution was concentrated to $15 \mathrm{ml}$ and left to stand overnight resulting in a yellow microcrystalline solid 4. (1.39 g, 43 \%) MS (EI, m/z) 1022 [M-ZnN(TMS) ${ }_{2}{ }^{+}$]. Found: C, 63.12; $\mathrm{H}$ 8.68; N, 2.22. $\mathrm{C}_{62} \mathrm{H}_{102} \mathrm{~N}_{2} \mathrm{NaO}_{4} \mathrm{Si}_{2} \mathrm{Zn}$ requires $\mathrm{C}, 62.97$; $\mathrm{H}, 8.69$; $\mathrm{N}, 2.37$ \%. IR (ATR, $\mathrm{cm}^{-1}$ ): 2955s, 2905m, 2869m, 1478s, $651390 \mathrm{~m}, 1361 \mathrm{~m}, 1303 \mathrm{~m}, 1250 \mathrm{~m}, 1194 \mathrm{~s}, 1124 \mathrm{w}, 1096 \mathrm{w}, 995 \mathrm{~m}$, 966s, 931s, 870s, 827s, 799m, 754m. ${ }^{1} \mathrm{H}$ NMR $\left(\mathrm{CDCl}_{3}\right): \delta=7.03$ (s, 4H, Ar- $H$ ), 6.76 (s, 4H, Ar-H), 4.50 (d, 4H, $J=12.1$, endo$\mathrm{CH}_{2}$ ), 4.06 (t, $4 \mathrm{H}, J=7.46, \mathrm{OCH}_{2} \mathrm{CH}_{2} \mathrm{CH}_{3}$ ), 3.16 (d, $4 \mathrm{H}, J=12.1$, exo- $\left.\mathrm{CH}_{2}\right), 1.91$ (m, 4H, $\left.J=7.47, \mathrm{OCH}_{2} \mathrm{CH}_{2} \mathrm{CH}_{3}\right), 1.28$ (s, $18 \mathrm{H}$, $\left.{ }_{70} \mathrm{C}\left(\mathrm{CH}_{3}\right)_{3}\right), 1.03$ (t, $\left.6 \mathrm{H}, J=7.45, \mathrm{OCH}_{2} \mathrm{CH}_{2} \mathrm{CH}_{3}\right), 0.90$ (s, $18 \mathrm{H}$, 
$\left.\mathrm{C}\left(\mathrm{CH}_{3}\right)_{3}\right), 0.11$ (overlapping s, 36H, N(SiMe $)_{2} \cdot{ }^{13} \mathrm{C} \quad \mathrm{NMR}$ $\left(\mathrm{CDCl}_{3}\right): \delta=156.3,148.4,145.1,138.0,131.2,131.1,124.8$, Table 3 Crystallographic data for compounds 1, 2, 3 and 6.

\begin{tabular}{|c|c|c|c|c|}
\hline Compound & 1 & 2 & 3 & 6 \\
\hline Formula & $\mathrm{C}_{62} \mathrm{H}_{66} \mathrm{~F}_{10} \mathrm{O}_{4} \mathrm{Zn}_{2}$ & $\mathrm{C}_{52} \mathrm{H}_{72} \mathrm{O}_{4} \mathrm{Zn}_{2}$ & $\mathrm{C}_{56} \mathrm{H}_{84} \mathrm{NNaO}_{4} \mathrm{Si}_{2} \mathrm{Zn}$ & $\begin{array}{c}\mathrm{C}_{126} \mathrm{H}_{137} \mathrm{~F}_{15} \mathrm{O}_{19} \mathrm{Zn}_{6} . \\
5 \mathrm{CH}_{3} \mathrm{CN}\end{array}$ \\
\hline Formula weight & 1195.89 & 891.89 & 979.80 & 2837.84 \\
\hline Crystal system & Triclinic & Triclinic & Triclinic & Triclinic \\
\hline Space group & $P \overline{1}$ & $P \overline{1}$ & $P \overline{1}$ & $P \overline{1}$ \\
\hline \multicolumn{5}{|l|}{ Unit cell dimensions } \\
\hline$a(\AA)$ & 10.935(3) & $12.4407(9)$ & $10.0724(7)$ & 16.9733(14) \\
\hline$b(\AA)$ & $15.653(4)$ & 13.4833(9) & 12.3152(9) & 20.4715(17) \\
\hline$c(\AA)$ & $18.150(5)$ & 24.1096(17) & 22.8866(16) & 21.2759(17) \\
\hline$\alpha\left(^{\circ}\right)$ & $95.911(4)$ & $90.508(5)$ & $81.897(3)$ & $91.246(6)$ \\
\hline$\beta\left(^{\circ}\right)$ & 105.236(3) & $100.609(6)$ & $88.440(3)$ & 109.931(8) \\
\hline$\gamma\left({ }^{\circ}\right)$ & $105.822(4)$ & 113.943(7) & 89.093(3) & $102.477(7)$ \\
\hline$V\left(\AA^{3}\right)$ & 2832.4(13) & $3617.2(5)$ & 2809.3(3) & 6749.0(10) \\
\hline Z & 2 & 3 & 2 & 2 \\
\hline Temperature (K) & $120(2)$ & $100(2)$ & $100(2)$ & $100(2)$ \\
\hline$D_{\text {calcd }}\left(\mathrm{Mg} / \mathrm{m}^{-3}\right)$ & 1.402 & 1.228 & 1.158 & 1.396 \\
\hline Absorption coefficient, $\mu\left(\mathrm{mm}^{-1}\right)$ & 0.869 & 1.036 & 0.530 & 1.135 \\
\hline Crystal size $\left(\mathrm{mm}^{3}\right)$ & $0.18 \times 0.05 \times 0.02$ & $0.050 \times 0.040 \times 0.020$ & $0.18 \times 0.13 \times 0.05$ & $0.11 \times 0.02 \times 0.01$ \\
\hline $2 \theta_{\max }\left({ }^{\circ}\right)$ & 26.0 & 27.5 & 27.5 & 22.5 \\
\hline Reflections measured & 24992 & 42558 & 48002 & 60159 \\
\hline Unique reflections, $R_{\mathrm{int}}$ & $11859,0.042$ & $16159,0.075$ & $12822,0.039$ & $17582,0.340$ \\
\hline Reflections with $F^{2}>2 \sigma\left(F^{2}\right)$ & 7445 & 11427 & 12053 & 5403 \\
\hline Transmission factors (max., min.) & 0.983 and 0.859 & 1.000 and 0.757 & 1.000 and 0.747 & 0.994 and 0.885 \\
\hline Number of parameters & 888 & 808 & 603 & 1766 \\
\hline$R_{1}\left[F^{2}>2 \sigma\left(F^{2}\right)\right]$ & 0.046 & 0.079 & 0.041 & 0.086 \\
\hline$w_{2}$ (all data) & 0.118 & 0.228 & 0.116 & 0.142 \\
\hline GOOF, $S$ & 0.989 & 1.041 & 1.055 & 0.807 \\
\hline $\begin{array}{l}\text { Largest difference peak } \\
\text { and hole }\left(\mathrm{e} \AA^{-3}\right)\end{array}$ & 0.387 and -0.337 & 2.818 and -1.586 & 0.901 and -0.806 & 0.505 and -0.448 \\
\hline
\end{tabular}

123.3, 79.2, 32.8, 32.6, 30.9, 30.1, 29.9, 19.7, 8.2, 3.9. 
caprolactone and was stirred for the allotted time. Conversion of monomer was determined by ${ }^{1} \mathrm{H}$ NMR spectroscopy, and the polymerization was quenched by addition of methanol

\section{5 rac-Lactide}

Solutions of rac-lactide and catalyst were prepared separately using the required solvent. The required amount of alcohol, from a standard alcohol solution in toluene, was added to the catalyst. The rac-lactide solution was added to the catalyst solution and 10 stirred for the allotted time at room temperature under nitrogen. $0.5-1.0 \mathrm{~mL}$ aliquots were taken out of the stirred solution where required and quenched with 1 drop of $0.1 \mathrm{M} \mathrm{HCl}$. The aliquots were then dried and analysed by ${ }^{1} \mathrm{H}$ NMR spectroscopy and GPC.

\section{${ }_{15}$ Crystallography}

Intensity data were collected on Bruker Apex 2 CCD diffratometer (1) or a Rigaku FR-E+ diffractometer (all others). For 1, data were measured using synchrotron radiation at SRS Daresbury station 9.8; all other data were measured with 20 monochromated Mo-K $\alpha$ radiation. Structures were determined by the direct methods routines in SHELXS-97 $(\mathbf{1}, \mathbf{6})^{21}$ or SIR-92 (2, 3), ${ }^{22}$ and were refined by full-matrix least-squares methods on $F^{2}$ in SHELXL-2013/2014. ${ }^{21}$ Non-hydrogen atoms were refined with anisotropic displacement parameters. Hydrogen atoms were 25 included in idealized positions and their $U_{\text {iso }}$ values were set to ride on the $U_{\text {eq }}$ values of the parent carbon atoms except for $\mathrm{H}(13)$ in 6 for which coordinates were refined with an $\mathrm{O}-\mathrm{H}$ distance restraint. Complex 2 contained a disordered solvent region which was handled using the BYPASS procedure. ${ }^{23}$ The 30 crystals of $\mathbf{6}$ were weakly diffracting, so data were only used to $\theta$ $=22.5^{\circ}$ and were of rather poor quality; the connectivity is however clearly determined.

Crystal data and refinement results for all samples are collated in Table 3. CCDC 1014114-1014117 contain the supplementary 35 crystallographic data for this paper. These data can be obtained free of charge from The Cambridge Crystallographic Data Centre via www.ccdc.cam.ac.uk/data_request/cif

\section{Conclusion}

40 In conclusion, we have structurally characterized a number of new zinc complexes bearing ligands derived from either 1,3dipropoxy-p-tert-butyl-calix[4]arene or p-tertbutylhexahomotrioxacalix[3]arene. These include a complex in which there are two different calixarene conformations in the 45 same structure, and an unusual structure bearing an oxacalix[3]arene derived ligand as well as two ring-opened ligands derived from the parent oxacalix[3]arene. Screening for the potential to ROP either $\varepsilon$-caprolactone ( $\varepsilon$-CL) and rac-lactide revealed that the presence of a $\mathrm{Zn}-\mathrm{C}_{6} \mathrm{~F}_{5}$ motif was detrimental in 50 the calix[4]arene systems, whilst use of the amide group $\mathrm{N}\left(\mathrm{SiMe}_{3}\right)_{2}$ proved to be more effective, with a $65 \%$ conversion over $4 \mathrm{~h}$ at ambient temperature.

\section{Notes and references}

${ }^{a}$ Energy Materials Laboratory, School of Chemistry, University of East 55 Anglia, Norwich, NR4 7TJ (UK)

${ }^{b}$ Chemistry Department, Loughborough University, Loughborough,

Leicestershire, LE11 3TU (UK)
${ }^{c}$ Department of Chemistry, University of Hull, Hull, HU6 7RX (UK), Email: c.redshaw@hull.ac.uk

$60 \dagger$ Electronic Supplementary Information (ESI) available: [details of any supplementary information available should be included here]. See DOI: $10.1039 / b 00000 x /$

1. B. M. Chamberlain, M. Cheng, D. R. Moore, T. M. Ovitt, E. 65 B. Lobkovsky and G. W. Coates, J. Am. Chem. Soc., 2001, 123, $3229-3238$

$2 . \quad$ C. Y. Li, P. S. Chen, S. J. Hsu, C. H. Lin, H. Y. Huang and B. T. Ko, J. Organomet Chem., 2012, 716, 175 - 181.

3. M. Bouyhayi, Y. Sarazin, O. L. Casagrande and J. F. $70 \quad$ Carpentier, Appl. Organomet. Chem., 2012, 26, 681 - 688.

$4 . \quad$ L. H. Yao, L. Wang, J. F. Zhang, N. Tang and J. C. Wu, J. Mol. Cat. A: Chemical, 2012, 352, 57 - 62.

5. D. M. Homden and C. Redshaw, Chem. Rev., 2008, 108, 5086 -5130 .

75 6. E. Bukhaltsev, L. Frish, Y. Cohen and A. Vigalok, Org. Lett., 2005, 7, $5123-5126$

7. M. J. Walton, S. J. Lancaster and C. Redshaw, ChemCatChem, 2014, 6, $1892-1898$.

8. See forexample, J. Jankowska, J. Paradowska, B. Rakiel and J. $80 \quad$ Mlynarski, J. Org. Chem.2007, 72, 2228 - 2231.

9. We note that the coordination chemistry of the oxacalix[3]arene system is somewhat scant, see (a) A. Arbaoui, C. Redshaw, M.R.J. Elsegood, V.E. Wright, A. Yoshizawa and T. Yamato, Chem. Asian J. 2010, 5, 621 - 633. 85 (b) S. M. Taylor, R. D. McIntosh, J. Reze, S. J. Dalgarno and E. K. Brechin, Chem. Commun., 2012, 48, 9263 - 9265.

10. K. Iwamoto, K. Araki and S. Shinkai, Tetrahedron, 1991, 47, $4325-4342$.

11. S. Kim, J.S. Kim, O.J. Shon, S.S. Lee, K.-M. Park, S.O. Kang $90 \quad$ and J. Ko, Inorg. Chem. 2004, 43, 2906-2913.

12. E. Bukhaltsev, I. Goldberg and A. Vigalok, Organometallics, 2004, 23, 4540 - 4543.

13. E. Piedra-Arroni, C. Ladaviere, A. Amgoune and D. Bourissou, J. Am. Chem. Soc., 2013, 135, 13306 - 13309.

$9514 . \quad$ G. Schnee, C. Fliedel, T. Avilés and S. Dagorne, Eur. J. Inorg. Chem., 2013, 2013, 3699 - 3709.

15. F. d. r. Drouin, P. O. Oguadinma, T. J. J. Whitehorne, R. E. Prud'homme and F. Schaper, Organometallics, 2010, 29, 2139 $-2147$.

$10016 . \quad$ C. Redshaw, M. A. Rowan, L. Warford, D. M. Homden, A. Arbaoui, M. R. J. Elsegood, S. H. Dale, T. Yamato, C. P. Casas, S. Matsui and S. Matsuura, Chem., Eur. J., 2007, 13, $1090-1107$.

$17 . \quad$ J. M. Notestein, L. R. Andrini, V. I. Kalchenko, F. G. Requejo, 105 A. Katz and E. Iglesia, J. Am. Chem. Soc., 2007, 129, $1122-$ 1131.

18. Y. Shen, Q. Tang, C. Zhang and W. Zhong, Synlett, 2012, 23, $741-746$.

19. I. Barakat, P. Dubois, R. Jérôme and P. Teyssié, J. Polymer 110 Sci. Part A: Polymer Chem., 1993, 31, 505-514.

20. J. Baran, A. Duda, A. Kowalski, R. Szymanski and S. Penczek, Macromol. Rapid Commun., 1997, 18, 325-333.

21. G. M. Sheldrick, Acta Crystallogr., Sect. A: Found. Crystallogr., 2008, 64, 112-122.

$11522 . \quad$ A. Altomare, G. Cascarano, C. Giacovazzo and A. Guagliardi, J. Appl. Crystallogr., 1994, 27, 435.

23. P. v.d. Sluis and A. L. Spek, Acta Crystallogr., Sect. A: Found. Crystallogr., 1990, 46, 194-201. 


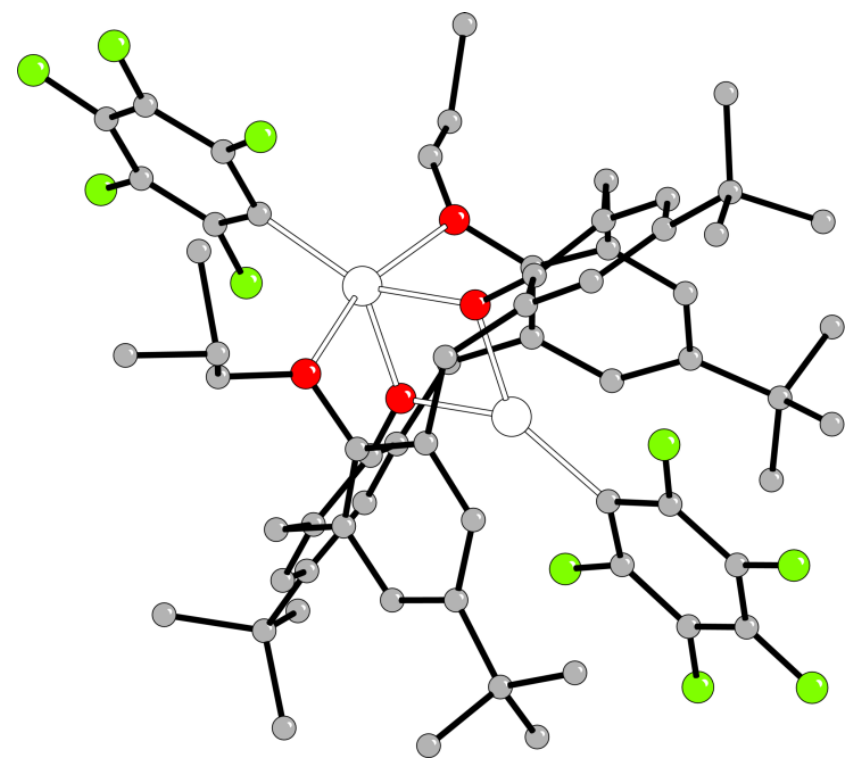

